\title{
In vitro Activity of Amorolfine, Ciclopirox, Itraconazole and Terbinafine Against Aspergillus versicolor as Agent of Onychomycosis
}

\section{Viviana Ramírez-Hernández, Carolina Montero-Arias, María Isabela Vargas-Ovalle, Mariana Villalobos-Vargas, Alejandra Gómez-Arrieta, Stefany Lozada-Alvarado, Ingrid Salas-Campos and Daniela Jaikel-Víquez*}

Sección De Micología Médica, Departamento De Microbiología, Facultad De Microbiología, Universidad De Costa Rica, San Pedro, Costa Rica

*Corresponding Author: Daniela Jaikel-Víquez, Sección de Micología Médica, Departamento de Microbiología, Facultad de Microbiología, Universidad de Costa Rica, San Pedro, Costa Rica.

DOI: 10.31080/ASMI.2020.03.0508
Received: January 17, 2020

Published: February 08, 2020

(C) All rights are reserved by Daniela

Jaikel-Víquez., et al.

\begin{abstract}
Cases of onychomycosis caused by non-dermatophyte filamentous fungi have increased over the years. It is worth noting that this group of fungi is resistant to fluconazole, thus the importance of determining the in vitro susceptibility patterns to the antifungals available. We determined the minimal inhibitory concentration of amorolfine, ciclopirox, itraconazole and terbinafine using the microdilution method M38-A, as described by the Clinical Laboratory and Standards Institute, of 13 isolates of Aspergillus versicolor obtained from onychomycosis. The final concentrations were: $0.13-64 \mu \mathrm{g} / \mathrm{mL}$ for amorolfine and terbinafine, $0.06-32 \mu \mathrm{g} / \mathrm{mL}$ for ciclopirox and 0.03-16 $\mathrm{g} / \mathrm{mL}$ for itraconazole. Also, we determined the interaction of these drugs by the checkerboard method. The $\mathrm{MIC}_{50}$ and $\mathrm{MIC}_{90}$ were $\geq 64.00$ and $\geq 64.00 \mu \mathrm{g} / \mathrm{mL}$ for amorolfine, 4.00 and $8.00 \mu \mathrm{g} / \mathrm{mL}$ for ciclopirox, 1.00 and $1.80 \mu \mathrm{g} / \mathrm{mL}$ for itraconazole and 0.50 and $1.36 \mu \mathrm{g} / \mathrm{mL}$ for terbinafine, respectively. Regarding the combination of antifungals, $15.38 \%$ of the combinations of ciclopirox-itraconazole presented synergism, while the rest of the combinations showed no interaction. Thus, in vitro susceptibility testing indicates that terbinafine exhibited the highest antifungal activity and amorolfine the lowest against $A$. versicolor. Also, combining treatments enhances the activity of the drugs, proving a possible alternative for successful treatment of onychomycosis caused by this fungus.
\end{abstract}

Keywords: Aspergillus versicolor; Amorolfine; Ciclopirox; Itraconazole; Terbinafine

\section{Abbreviations}

CLSI: Clinical and Laboratory Standard Institute; FIC: Fractional Inhibitory Concentration; FICI: Fractional Inhibitory Concentration Index; MIC: Minimal Inhibitory Concentration; NDFF: NonDermatophyte Filamentous Fungi; PDA: Potato Dextrose Agar; RPMI: Roswell Park Memorial Institute; MOPS: Morpholine Propanesulphonic Acid

\section{Introduction}

Onychomycosis is an infection of the nail apparatus caused by fungi. Currently, it is considered a public health problem since it has been reported worldwide and cases are on the rise [1]. This disease is mainly caused by dermatophytes, followed by Candida spp. and finally by non-dermatophyte filamentous fungi (NDFF) [1]. The latter group is made up of fast-growing microorganisms that are widely distributed in nature. Traditionally, they have been regarded as laboratory contaminants. Therefore, in order to consider them as etiological agents of onychomycosis, their isolation must be accompanied by the presence of septate, hyaline or dematiaceous mycelium in the clinical sample [2]. Among the genera reported are: Acremonium, Aspergillus, Chrysosporium, Fusarium, Neoscytalidium, Onychocola, Penicillium, Scopulariopsis and Trichosporon [3-5]. In Costa Rica, Fusarium spp. is the most frequently isolated NDFF from toenails and Trichosporon spp. from fingernails, but also Scopulariopsis spp. and Aspergillus versicolor have been isolated [2,5]. A. versicolor, is a ubiquitous fungus that produces velvety colonies, which at first are white and then turn yellow, orangey, tan, green or pinkish. The reverse of the colony can be white, yellow, orange or red. Microscopically, it is characterized by the production of conidiophores that are enlarged at the tip, forming a swollen vesicle. This vesicle is mostly covered by two rows of phyalides (biseriated) [6].

These infections are difficult to treat, as the nail has several intrinsic factors such as: slow growth and little vascularity which make it difficult for the antifungal agent to reach its target, the area and percentage of the affected nail, the etiological agent involved, 
coexistence of various fungi and non-compliance with treatment by patients [7-9]. Also, NDFF are usually resistant to the available treatments [3]. For example, Scopulariopsis sp. and A. versicolor are resistant, in vitro, to fluconazole and itraconazole $[10,11]$ and $F u$ sarium to itraconazole and terbinafine [12]. As a result, studies involving the determination of the antifungal activity of the different compounds against NDFF have increased, highlighting the importance of identifying the etiological agent of the condition in order to provide the best therapeutic option for the patients [13]. Thus, the present study aims to determine the in vitro susceptibility patterns of two systemic antifungal agents (itraconazole and terbinafine) and two topical treatments (amorolfine and ciclopirox) against isolates of $A$. versicolor obtained from onychomycosis.

\section{Materials and Methods}

Strains

A total of thirteen clinical isolates of $A$. versicolor were included in this study. The isolates were preserved at the Fungal Collection of the Section of Medical Mycology, School of Microbiology, University of Costa Rica. They were obtained from patients with onychomycosis from 2006 to 2016; it is worth noting that each isolate originated from a unique clinical specimen. All isolates were maintained in Czapek Dox Agar and Potato Dextrose Agar (PDA) (OXOIDTM, Thermo Fisher Scientific, Waltham, Massachusetts, USA) at $20-25^{\circ} \mathrm{C}$.

\section{Preparation of the fungal inoculum}

The isolates were grown for 7 days at $20-25^{\circ} \mathrm{C}$ in test tubes containing PDA. The conidia were collected by adding $5 \mathrm{~mL}$ of $85 \%$ sterile saline solution to the test tubes and then probing the colonies with the tip of a sterile Pasteur pipette. Conidia concentration was determined with a Neubauer hemocytometer (Hausser Scientific Horsham, PA, USA) and standardized to $1-5 \times 10^{6}$ spores $/ \mathrm{mL}$. Suspensions were later diluted 1:50 in RPMI 1640 Medium (Roswell Park Memorial Institute) (Thermo Fisher Scientific, USA) (2 $\times 10^{4}-1 \times 10^{5}$ spores $/ \mathrm{mL}$ ). One hundred microliters of this suspension were added to the wells with the antifungal compounds. Hence, the final spore concentrations were $1-5 \times 10^{4}$ spores $/ \mathrm{mL}$.

\section{Antifungal agents}

The antifungal agents used in this study were: amorolfine, ciclopirox, itraconazole and terbinafine (Royal Pharm, Hanghou, China). They were obtained as standard powder and the stock solution was prepared in RPMI 1640 with glutamine and without bicarbonate, buffered to $\mathrm{pH} 7$ with morpholine propanesulphonic acid (MOPS) to yield twice the final concentration required for the test.

\section{Microdilution method}

The minimal inhibitory concentration (MIC) was determined by the microdilution method, according to the Clinical and Laboratory
Standard Institute (CLSI) document M38-A [14]. The final concentrations were: amorolfine $(0.13-64) \mu \mathrm{g} / \mathrm{mL}$, ciclopirox $(0.06-32)$ $\mu \mathrm{g} / \mathrm{mL}$, itraconazole $(0.03-16) \mu \mathrm{g} / \mathrm{mL}$ and terbinafine $(0.13-64)$ $\mu \mathrm{g} / \mathrm{mL}$. The quality control strains used were: Candida krusei ATCC 6258 and Candida parapsilosis ATCC 22019. Spectrophotometric readings were made at 72 hours of incubation at $450 \mathrm{~nm}$ with a Synergy HT (BioTek Instruments, Inc., Winooski, VT, USA). Geometric means, MIC ranges, $\mathrm{MIC}_{50}$ and $\mathrm{MIC}_{90}$ were calculated for each antifungal agent. The significant differences in mean values were determined by a one-way ANOVA test with Tukey post-test, using the program SPSS for Windows, version 20 (SPSS Inc., Chicago, Ill, USA). P-values $<0.05$ were considered statistically significant.

\section{Drug synergy assay}

The in vitro drug interaction study was determined using the checkerboard titration method, as described previously [15]. Briefly, synergistic/additive/antagonist interactions of ciclopirox, itraconazole and terbinafine against $A$. versicolor were evaluated by determining MICs of the drugs alone and in combination in 96-well plates. Each combination was prepared so that the initial concentration of each drug was 4-fold the MIC. Serial dilutions were made in subsequent wells. $100 \mu \mathrm{L}$ of the fungal inoculum (final conidia concentration of $1-5 \times 10^{4}$ spores $/ \mathrm{mL}$ ) were added to each well. The plates were incubated at $(20-25){ }^{\circ} \mathrm{C}$ for 72 hours and then read by spectrophotometry with a Synergy HT (Bio Tek Instruments, Inc., Winooski, VT, USA). The combination reductions in MICs were used to calculate the fractional inhibitory concentration (FIC). FIC indices (FICI) were interpreted as follows: $\leq 0.5$, synergism; $>0.5$ to $<4.0$, no interaction/indifference; and $\geq 4.0$, antagonism [16]. All tests were performed in duplicate. FICI ranges were calculated for each antifungal combination. Finally, the significant differences in mean values between the MICs of alone and combined treatments and the differences between the FICI were determined by a oneway ANOVA test with Tukey post-test, using the program SPSS for Windows, version 20 (SPSS Inc., Chicago, Ill, USA). P-values $<0.05$ were considered statistically significant.

\section{Results and Discussion}

Determination of the minimal inhibitory concentration

Resistance to treatment by NDFF, that produce onychomycosis, has led to numerous studies and different therapeutic schemes. In order to improve the treatment for this fungal group, we determined the in vitro susceptibility patterns of two systemic antifungal agents (itraconazole and terbinafine) and two topical treatments (amorolfine and ciclopirox) against isolates of A. versicolor obtained from onychomycosis. Table 1 shows the distribution of MICs for the 13 isolates. Statistically significant differences were found between the MIC averages of the drugs tested $(\mathrm{F}=8753.73$; $\mathrm{df}=$ $3 ; \mathrm{p}<0.0001$ ). As a result of these significant differences, a Tukey post-test was performed. This analysis grouped the treatments into 


\begin{tabular}{|l|c|c|c|c|}
\hline \multirow{2}{*}{$\begin{array}{c}\text { Antifungal } \\
\text { agent }\end{array}$} & \multicolumn{4}{|c|}{ MIC* $(\boldsymbol{\mu g} / \mathbf{m L})$} \\
\cline { 2 - 5 } & Geometric mean (SD) & Range & MIC $_{\mathbf{5 0}}$ & MIC $_{\mathbf{9 0}}$ \\
\hline Amorolfine & $64.00( \pm 0.00)$ & - & $\geq 64.00$ & $\geq 64.00$ \\
\hline Ciclopirox & $4.89( \pm 2.30)$ & $1.60-8.00$ & 4.00 & 8.00 \\
\hline Itraconazole & $0.86( \pm 0.50)$ & $0.13-2.00$ & 1.00 & 1.80 \\
\hline Terbinafine & $0.55( \pm 0.43)$ & $0.13-1.60$ & 0.50 & 1.36 \\
\hline
\end{tabular}

Table 1: In vitro susceptibility patterns of Costa Rican isolates of A. versicolor $(\mathrm{n}=13)$ isolated from onychomycosis.

*MIC: minimal inhibitory concentration.

three groups. In the first one, itraconazole and terbinafine were included, since they had the highest antifungal activity (lower MIC). On the other hand, the topical antifungals were grouped separately, in the other two groups.

In regard to the systemic treatments, a $\mathrm{MIC}_{50}$ of $0.50 \mu \mathrm{g} / \mathrm{mL}$ and a $\mathrm{MIC}_{90}$ of $1.36 \mu \mathrm{g} / \mathrm{mL}$ were obtained for terbinafine. These results are consistent with Torres., et al. (1998), since they reported a $\mathrm{MIC}_{50}$ of $0.25 \mu \mathrm{g} / \mathrm{mL}$ and a $\mathrm{MIC}_{90}$ of $0.75 \mu \mathrm{g} / \mathrm{mL}$ by the broth microdilution method for12 isolates of $A$. versicolor obtained from onychomycosis in Spain [10]. This treatment is also effective against dermatophytes as shown by Díaz., et al. (2015) who studied 62 dermatophyte isolates from Chile obtaining MICs ranging from 0.03 to $0.06 \mu \mathrm{g} / \mathrm{mL}$ [17]. On the other hand, in the present study, seven of the isolates were resistant to itraconazole, with a $\mathrm{MIC}_{50}$ of $1.00 \mu \mathrm{g} / \mathrm{mL}$ These results are in concordance with Torres., et al. (1998) that reported a $91.7 \%$ resistance to this compound. However, the MICs found in the present study are higher than those published by Chavez., et al. (2010) in Colombia, where the authors reported a $\mathrm{MIC}_{50}$ of $0.38 \mu \mathrm{g} / \mathrm{mL}$ for an isolate of $A$. versicolor, by using the E-Test ${ }^{\circledR}$ method [18] or by García-Martos., et al. (2005) from Spain, who reported a $\mathrm{MIC}_{50}$ of $0.5 \mu \mathrm{g} / \mathrm{mL}$ for five isolates of $A$. versicolor, by the microdilution method with Sensititre Yeast One ${ }^{\circledR}$ [19]. As previously stated, Aspergillus are environmental fungi, so it is considered that their development of resistance could be due to the use of pesticides in agriculture; in addition, cross-resistance has been observed with other azoles such as voriconazole and posaconazole. The most common resistance mechanism is a replacement of a leucine by a histidine at position 98 , in the cyp51A gene [20-22]. Mechanisms of azole resistance have been reported in strains of Aspergillus fumigatus, including point mutations in two genes; cyp51A and cyp51B encoding for 14- $\alpha$ lanosterol demethylase. This mutation causes the loss of drug affinity at the catalytic site [23]. In addition, an increase in the number and activity of efflux pumps (ABC: ATP Binding Cassette and MFS: Mayor Facilitators Superfamily) have been described [24,25].

When it comes to topical treatments, the postulated antimycotic mechanism of action of ciclopirox is the chelation of polyvalent metal cations, especially iron $\left(\mathrm{FE}^{3+}\right)$, which leads to the inhibition of metal-dependent enzymes (cytochromes, catalases and peroxidases) [26]. For this drug, we obtained a $\mathrm{MIC}_{50}$ of $4.00 \mu \mathrm{g} / \mathrm{mL}$ and a $\mathrm{MIC}_{90}$ of $8.00 \mu \mathrm{g} / \mathrm{mL}$. To our knowledge, this is the first study which aims to determine the in vitro susceptibility of $A$. versicolor to ciclopirox. However, in 2017, Liu., et al. published a case report of a patient with primary cutaneous aspergillosis caused by $A$. fumigatus that was successfully treated with oral itraconazole and ciclopirox olamine ointment [27]. Finally, 100\% of the isolates had a MIC $\geq 64.00 \mu \mathrm{g} / \mathrm{mL}$ for amorolfine. This data is consistent with Li., et al. (2004) who reported an isolate of Aspergillus flavus obtained from a patient with dermatomycosis with a MIC $\geq 64.00 \mu \mathrm{g} /$ $\mathrm{mL}$ for this drug. In the other hand, this antifungal agent has proven to be a possible therapeutic option for infections caused by dermatophytes such as Trichophyton rubrum ( $\mathrm{MIC}_{50} 0.01 \mu \mathrm{g} / \mathrm{mL}$ ), Trichophyton mentagrophytes $\left(\mathrm{MIC}_{50} 0.04 \mu \mathrm{g} / \mathrm{mL}\right.$ ) and Epidermophyton floccosum ( $\mathrm{MIC}_{50} 0.02 \mu \mathrm{g} / \mathrm{mL}$ ) [28] and other NDFF like Fusrium solani ( $\mathrm{MIC}_{50} 1.25 \mu \mathrm{g} / \mathrm{mL}$ ) [12] and Scopulariopsis spp. ( $\mathrm{MIC}_{50} 0.13$ $\mu \mathrm{g} / \mathrm{mL}$ ] [11].

\section{Drug synergy assay}

Tables 2 - 4 show the MICs of the antifungal drugs obtained after their combination with other treatments and the FICIs for the combinations studied. $15.38 \%$ of the combinations of ciclopiroxitraconazole presented synergism while the rest of the combinations showed no interaction. However, it is worth noting that, statistical differences were found between the geometric means of the MICs obtained for ciclopirox $(\mathrm{F}=12,311 ; \mathrm{df}=2 ; \mathrm{p}<0,001)$ and terbinafine $(\mathrm{F}=5,127 ; \mathrm{df}=2 ; \mathrm{p}<0,05)$ when compared to the MICs obtained after the combination. In both cases, Tukey test grouped the MIC of the antifungal when tested alone in one group and the MICs in combination in another. In contrast, there were no statistical differences found between the MICs for itraconazole alone or in combination with terbinafine or ciclopirox $(\mathrm{F}=3,007 ; \mathrm{df}=2 ; \mathrm{p}$ $=0,062)$. Nevertheless, $53.85 \%(n=7)$ of the isolates were resistant to itraconazole (MIC $\geq 1,00 \mu \mathrm{g} / \mathrm{mL}$ ) when tested alone but only $15.39 \%(n=2)$ were resistant when combined with terbinafine or ciclopirox. Finally, there were no statistical differences found between the FICI of the three combinations ( $\mathrm{F}=1,731$; $\mathrm{gl}=2 ; \mathrm{p}=$ 0,191).

When analyzing the drug-drug interaction, through the FICI, within the results obtained in our research, a possible enhancing effect was found between the combinations itraconazole - terbinafine and ciclopirox - terbinafine and ciclopirox - itraconazole. In fact, synergism was found within the latter combination. Dorsthorst., et al. (2002) and Gupta (2003) obtained similar results to ours, the first obtained synergism for all strains of $A$. fumigatus subjected to the combination itraconazole - terbinafine [15] and Gupta synergism and/or additive $(0.5<$ FICI $\leq 1.00)$ reactions for the combinations ciclopirox - terbinafine and ciclopirox - itraconazole [29]. Like us, none of them obtained cases of antagonism [15,29]. The usage of antifungal combinations is beneficial for the patient since 


\begin{tabular}{|c|c|c|c|c|c|}
\hline \multirow{2}{*}{ Strain } & \multirow{2}{*}{$\begin{array}{l}\text { Antifungal } \\
\text { agent }\end{array}$} & \multicolumn{2}{|c|}{ MIC ${ }^{a}$ of ITZ $(\mu \mathrm{g} / \mathrm{mL})$} & \multicolumn{2}{|c|}{ Interaction } \\
\hline & & Alone & Combination & FICI $^{\mathrm{b}}$ & Type \\
\hline \multirow[t]{2}{*}{ AS VE 01} & $\mathrm{ITZ}^{\mathrm{c}}+\mathrm{CIC}^{\mathrm{d}}$ & 0.50 & 0.50 & 1.25 & No interaction \\
\hline & $\mathrm{ITZ}+\mathrm{TB}^{\mathrm{e}}$ & 0.50 & 0.25 & 1.00 & No interaction \\
\hline \multirow[t]{2}{*}{ AS VE 02} & $\mathrm{ITZ}+\mathrm{CIC}$ & 0.13 & 0.03 & 0.48 & Synergy \\
\hline & $\mathrm{ITZ}+\mathrm{TB}$ & 0.13 & 0.02 & 0.65 & No interaction \\
\hline \multirow[t]{2}{*}{ AS VE 03} & $\mathrm{ITZ}+\mathrm{CIC}$ & 1.00 & 1.00 & 2.00 & No interaction \\
\hline & $\mathrm{ITZ}+\mathrm{TB}$ & 1.00 & 0.50 & 0.63 & No interaction \\
\hline \multirow[t]{2}{*}{ AS VE 04} & $\mathrm{ITZ}+\mathrm{CIC}$ & 1.00 & 0.50 & 0.63 & No interaction \\
\hline & $\mathrm{ITZ}+\mathrm{TB}$ & 1.00 & 0.06 & 0.56 & No interaction \\
\hline \multirow[t]{2}{*}{ AS VE 05} & $\mathrm{ITZ}+\mathrm{CIC}$ & 2.00 & 1.00 & 0.75 & No interaction \\
\hline & $\mathrm{ITZ}+\mathrm{TB}$ & 2.00 & 2.00 & 2.00 & No interaction \\
\hline \multirow[t]{2}{*}{ AS VE 06} & $\mathrm{ITZ}+\mathrm{CIC}$ & 0.50 & 0.25 & 0.75 & No interaction \\
\hline & $\mathrm{ITZ}+\mathrm{TB}$ & 0.50 & 1.00 & 3.00 & No interaction \\
\hline \multirow[t]{2}{*}{ AS VE 07} & $\mathrm{ITZ}+\mathrm{CIC}$ & 0.50 & 0.13 & 0.29 & Synergy \\
\hline & $\mathrm{ITZ}+\mathrm{TB}$ & 0.50 & 0.50 & 1.50 & No interaction \\
\hline \multirow[t]{2}{*}{ AS VE 08} & $\mathrm{ITZ}+\mathrm{CIC}$ & 1.50 & 0.75 & 0.75 & No interaction \\
\hline & $\mathrm{ITZ}+\mathrm{TB}$ & 1.50 & 0.75 & 0.62 & No interaction \\
\hline \multirow[t]{2}{*}{ AS VE 09} & $\mathrm{ITZ}+\mathrm{CIC}$ & 1.00 & 0.50 & 1.00 & No interaction \\
\hline & $\mathrm{ITZ}+\mathrm{TB}$ & 1.00 & 0.50 & 1.01 & No interaction \\
\hline \multirow[t]{2}{*}{ AS VE 10} & ITZ + CIC & 0.50 & 0.50 & 0.63 & No interaction \\
\hline & $\mathrm{ITZ}+\mathrm{TB}$ & 0.50 & 0.13 & 0.76 & No interaction \\
\hline \multirow[t]{2}{*}{ AS VE 11} & $\mathrm{ITZ}+\mathrm{CIC}$ & 0.50 & 0.13 & 0.76 & No interaction \\
\hline & $\mathrm{ITZ}+\mathrm{TB}$ & 0.50 & 0.25 & 0.75 & No interaction \\
\hline \multirow[t]{2}{*}{ AS VE 12} & ITZ + CIC & 1.00 & 0.13 & 0.63 & No interaction \\
\hline & $\mathrm{ITZ}+\mathrm{TB}$ & 1.00 & 0.50 & 1.00 & No interaction \\
\hline \multirow[t]{2}{*}{ AS VE 13} & ITZ + CIC & 1.00 & 0.50 & 0.63 & No interaction \\
\hline & $\mathrm{ITZ}+\mathrm{TB}$ & 1.00 & 0.50 & 1.04 & No interaction \\
\hline
\end{tabular}

\begin{tabular}{|c|c|c|c|c|c|}
\hline \multirow{2}{*}{ Strain } & \multirow{2}{*}{$\begin{array}{l}\text { Antifungal } \\
\text { agent }\end{array}$} & \multicolumn{2}{|c|}{ MIC $^{\mathrm{a}}$ of ITZ $(\mu \mathrm{g} / \mathrm{mL})$} & \multicolumn{2}{|c|}{ Interaction } \\
\hline & & Alone & Combination & FICI $^{\mathrm{b}}$ & Type \\
\hline \multirow[t]{2}{*}{ AS VE 01} & $\mathrm{CIC}^{\mathrm{c}}+\mathrm{ITZ}^{\mathrm{d}}$ & 8.00 & 2.00 & 1.25 & No interaction \\
\hline & $\mathrm{CIC}+\mathrm{TB}^{\mathrm{e}}$ & 8.00 & 4.00 & 1.00 & No interaction \\
\hline \multirow[t]{2}{*}{ AS VE 02} & $\mathrm{CIC}+\mathrm{ITZ}$ & 2.00 & 0.50 & 0.48 & Synergy \\
\hline & $\mathrm{CIC}+\mathrm{TB}$ & 2.00 & 1.00 & 0.65 & No interaction \\
\hline \multirow[t]{2}{*}{ AS VE 03} & CIC + ITZ & 6.00 & 6.00 & 2.00 & No interaction \\
\hline & $\mathrm{CIC}+\mathrm{TB}$ & 6.00 & 3.00 & 0.75 & No interaction \\
\hline \multirow[t]{2}{*}{ AS VE 04} & CIC + ITZ & 8.00 & 1.00 & 0.63 & No interaction \\
\hline & $\mathrm{CIC}+\mathrm{TB}$ & 8.00 & 4.00 & 1.00 & No interaction \\
\hline \multirow[t]{2}{*}{ AS VE 05} & CIC + ITZ & 2.00 & 0.50 & 0.75 & No interaction \\
\hline & $\mathrm{CIC}+\mathrm{TB}$ & 2.00 & 1.00 & 1.04 & No interaction \\
\hline \multirow[t]{2}{*}{ AS VE 06} & CIC + ITZ & 4.00 & 1.00 & 0.75 & No interaction \\
\hline & $\mathrm{CIC}+\mathrm{TB}$ & 4.00 & 2.00 & 0.76 & No interaction \\
\hline \multirow[t]{2}{*}{ AS VE 07} & CIC + ITZ & 8.00 & 0.25 & 0.29 & Synergy \\
\hline & $\mathrm{CIC}+\mathrm{TB}$ & 8.00 & 4.00 & 1.02 & No interaction \\
\hline \multirow[t]{2}{*}{ AS VE 08} & CIC + ITZ & 4.00 & 1.00 & 0.75 & No interaction \\
\hline & $\mathrm{CIC}+\mathrm{TB}$ & 4.00 & 2.00 & 1.02 & No interaction \\
\hline \multirow[t]{2}{*}{ AS VE 09} & CIC + ITZ & 6.00 & 3.00 & 1.00 & No interaction \\
\hline & $\mathrm{CIC}+\mathrm{TB}$ & 6.00 & 3.00 & 0.85 & No interaction \\
\hline \multirow[t]{2}{*}{ AS VE 10} & CIC + ITZ & 4.00 & 0.50 & 0.63 & No interaction \\
\hline & $\mathrm{CIC}+\mathrm{TB}$ & 4.00 & 2.00 & 0.63 & No interaction \\
\hline \multirow[t]{2}{*}{ AS VE 11} & CIC + ITZ & 4.00 & 2.00 & 0.76 & No interaction \\
\hline & $\mathrm{CIC}+\mathrm{TB}$ & 4.00 & 2.00 & 0.76 & No interaction \\
\hline \multirow[t]{2}{*}{ AS VE 12} & CIC + ITZ & 6.00 & 3.00 & 0.63 & No interaction \\
\hline & $\mathrm{CIC}+\mathrm{TB}$ & 6.00 & 0.19 & 0.53 & No interaction \\
\hline \multirow[t]{2}{*}{ AS VE 13} & CIC + ITZ & 1.60 & 0.20 & 0.63 & No interaction \\
\hline & $\mathrm{CIC}+\mathrm{TB}$ & 1.60 & 0.80 & 0.58 & No interaction \\
\hline
\end{tabular}

Table 2: Minimal inhibitory concentration of itraconazole alone and in combination with ciclopirox or terbinafine of Costa Rican isolates of A. versicolor ( $\mathrm{n}=13$ ) isolated from onychomycosis

a MIC: minimal inhibitory concentration.

bFICI: fractional inhibitory concentration index. Drug interactions were classified as synergistic (FICI $\leq 0.5)$, no interaction $(0.5<$

FICI $<4$ ) or antagonistic (FICI $\geq 4$ ).

cITZ: Itraconazole.

dCIC: Ciclopirox.

eTB: Terbinafine.

Table 3: Minimal inhibitory concentration of ciclopirox alone and in combination with itraconazole or terbinafine of Costa Rican isolates of A. versicolor $(\mathrm{n}=13)$ isolated from onychomycosis a MIC: minimal inhibitory concentration

bFICI: fractional inhibitory concentration index. Drug interactions were classified as synergistic (FICI $\leq 0.5)$, no interaction $(0.5<$ FICI $<4)$ or antagonistic $(\mathrm{FICI} \geq 4)$.
cCIC: Ciclopirox
dITZ: Itraconazole
eTB: Terbinafine. 


\begin{tabular}{|c|c|c|c|c|c|}
\hline \multirow{2}{*}{ Strain } & \multirow{2}{*}{$\begin{array}{c}\text { Antifungal } \\
\text { agent }\end{array}$} & \multicolumn{2}{|c|}{ MIC ${ }^{\mathrm{a}}$ of ITZ $(\mu \mathrm{g} / \mathrm{mL})$} & \multicolumn{2}{|c|}{ Interaction } \\
\hline & & Alone & Combination & FICI $^{\mathrm{b}}$ & Type \\
\hline \multirow[t]{2}{*}{ AS VE 01} & $\mathrm{~TB}^{\mathrm{c}}+\mathrm{CIC}^{\mathrm{d}}$ & 0.50 & 0.25 & 1.00 & No interaction \\
\hline & $\mathrm{TB}+\mathrm{ITZ}^{\mathrm{e}}$ & 0.50 & 0.25 & 1.00 & No interaction \\
\hline \multirow[t]{2}{*}{ AS VE 02} & $\mathrm{~TB}+\mathrm{CIC}$ & 0.13 & 0.02 & 0.65 & No interaction \\
\hline & $\mathrm{TB}+\mathrm{ITZ}$ & 0.13 & 0.07 & 0.65 & No interaction \\
\hline \multirow[t]{2}{*}{ AS VE 03} & $\mathrm{~TB}+\mathrm{CIC}$ & 1.00 & 0.25 & 0.75 & No interaction \\
\hline & $\mathrm{TB}+\mathrm{ITZ}$ & 1.00 & 0.13 & 0.63 & No interaction \\
\hline \multirow[t]{2}{*}{ AS VE 04} & $\mathrm{~TB}+\mathrm{CIC}$ & 0.50 & 0.25 & 1.00 & No interaction \\
\hline & $\mathrm{TB}+\mathrm{ITZ}$ & 0.50 & 0.25 & 0.56 & No interaction \\
\hline \multirow[t]{2}{*}{ AS VE 05} & $\mathrm{~TB}+\mathrm{CIC}$ & 0.13 & 0.07 & 1.04 & No interaction \\
\hline & $\mathrm{TB}+\mathrm{ITZ}$ & 0.13 & 0.13 & 2.00 & No interaction \\
\hline \multirow[t]{2}{*}{ AS VE 06} & $\mathrm{~TB}+\mathrm{CIC}$ & 0.50 & 0.13 & 0.76 & No interaction \\
\hline & $\mathrm{TB}+\mathrm{ITZ}$ & 0.50 & 0.50 & 3.00 & No interaction \\
\hline \multirow[t]{2}{*}{ AS VE 07} & $\mathrm{~TB}+\mathrm{CIC}$ & 0.50 & 0.26 & 1.02 & No interaction \\
\hline & $\mathrm{TB}+\mathrm{ITZ}$ & 0.50 & 0.25 & 1.50 & No interaction \\
\hline \multirow[t]{2}{*}{ AS VE 08} & $\mathrm{~TB}+\mathrm{CIC}$ & 0.25 & 0.13 & 1.02 & No interaction \\
\hline & $\mathrm{TB}+\mathrm{ITZ}$ & 0.25 & 0.03 & 0.62 & No interaction \\
\hline \multirow[t]{2}{*}{ AS VE 09} & $\mathrm{~TB}+\mathrm{CIC}$ & 0.38 & 0.13 & 0.85 & No interaction \\
\hline & $\mathrm{TB}+\mathrm{ITZ}$ & 0.38 & 0.19 & 1.01 & No interaction \\
\hline \multirow[t]{2}{*}{ AS VE 10} & $\mathrm{~TB}+\mathrm{CIC}$ & 1.00 & 0.13 & 0.63 & No interaction \\
\hline & $\mathrm{TB}+\mathrm{ITZ}$ & 1.00 & 0.50 & 0.76 & No interaction \\
\hline \multirow[t]{2}{*}{ AS VE 11} & $\mathrm{~TB}+\mathrm{CIC}$ & 0.50 & 0.13 & 0.76 & No interaction \\
\hline & $\mathrm{TB}+\mathrm{ITZ}$ & 0.50 & 0.13 & 0.75 & No interaction \\
\hline \multirow[t]{2}{*}{ AS VE 12} & $\mathrm{~TB}+\mathrm{CIC}$ & 1.60 & 0.80 & 0.53 & No interaction \\
\hline & $\mathrm{TB}+\mathrm{ITZ}$ & 1.60 & 0.80 & 1.00 & No interaction \\
\hline \multirow[t]{2}{*}{ AS VE 13} & $\mathrm{~TB}+\mathrm{CIC}$ & 0.13 & 0.01 & 0.58 & No interaction \\
\hline & TB + ITZ & 0.13 & 0.07 & 1.04 & No interaction \\
\hline
\end{tabular}

Table 4: Minimal inhibitory concentration of terbinafine alone and in combination with ciclopirox or itraconazole of Costa Rican isolates of $A$. versicolor $(\mathrm{n}=13)$ isolated from onychomycosis

a MIC: minimal inhibitory concentration

bFICI: fractional inhibitory concentration index. Drug interactions were classified as synergistic (FICI $\leq 0.5)$, no interaction $(0.5<$

FICI $<4$ ) or antagonistic (FICI $\geq 4)$.

$$
\begin{gathered}
\text { c TB: Terbinafine } \\
\text { d CIC: Ciclopirox } \\
\text { e ITZ: Itraconazole. }
\end{gathered}
$$

this therapeutical scheme may reduce toxicity and the development of resistance [30].

\section{Conclusion}

In vitro susceptibility testing indicates that terbinafine exhibits the highest antifungal activity and amorolfine the lowest against A. versicolor. Also, combining treatments enhances the activity of the drugs, proving a possible alternative for successful treatment of onychomycosis caused by this fungus.

\section{Acknowledgements}

The study was funded by the Vicerrectoría de Investigación, Universidad de Costa Rica, project B8118.

\section{Conflict of Interest}

The authors declare that there is no conflict of interest involved in this article.

\section{Bibliography}

1. Pérez JE. "La onicomicosis: de sus implicaciones cosméticas a las dificultades en su tratamiento". Biosalud 10.1 (2011): 5-6.

2. Salas-Campos I., et al. "Agentes etiológicos de onicomicosis diagnosticadas en el laboratorio de micología médica de la Universidad de Costa Rica”. Acta Médica Costarricense 54.2 (2012): 114-118.

3. Asbati M., et al. "Onicomicosis por hongos no dermatofitos: Estudio retrospectivo en 4 años". Revista de la Sociedad Venezolana de Microbiología 22.2 (2002): 147-152.

4. Mügge C., et al. "Causative agents of onychomycosis - a retrospective study". Journal der Deutschen Dermatologischen Gesellschaft 4.3 (2006): 218-227.

5. Salas-Campos I., et al. "Onicomicosis por hongos fuliginosos". Acta Médica Costarricense 51.4 (2009): 241-244.

6. Gross-Martínez NT., et al. "Métodos diagnósticos en micología médica”. 1st ed. San José: Editorial UCR (2012).

7. Llambrich A., et al. "Tratamiento actual de las onicomicosis". Revista Iberoamericana de Micología 19 (2002): 127-129.

8. Escobar M., et al. "Onicomicosis por hongos ambientales no dermatofitos". Revista Iberoamericana de Micología 20 (2003): 6-10.

9. Carrillo-Muñoz A., et al. "Antifúngicos para el tratamiento de las micosis ungueales". Revista Iberoamericana de Micología 27 (2010): 49-56.

10. Torres-Rodríguez JM., et al. "Aspergillus versicolor as cause of onychomycosis: report of 12 cases and susceptibility testing to antifungal drugs". Journal of the European Academy of Dermatology and Venereology 11.1 (1998): 25-31.

11. Barrantes-Ortiz N., et al. "Susceptibilidad in vitro a antifúngicos de aislamientos de Scopulariopsis sp. provenientes de onicomicosis". Dermatología Revista México 63.3 (2019): 261267.

12. Sequeira-Oviedo PM., et al. "Susceptibilidad antimicrobiana de los aislamientos de Fusarium solani provenientes de onicomicosis". Dermatología Revista México 61.3 (2017): 197-205. 
13. Carrillo-Muñoz A., et al. "In vitro activity of voriconazole against dermatophytes, Scopulariopsis brevicaulis and other opportunistic fungi as agents of onychomycosis". International Journal of Antimicrobial Agents 30.2 (2007): 157-161.

14. Cantón R., et al. "Capítulo 15 Métodos estandarizados por el CLSI para el estudio de la sensibilidad a los antifúngicos (documentos M27-A3, M38-A y M44-A)". En: Pemán J, Martín-Mazuelos E, Rubio-Calvo MC, editores. Guía Práctica de Identificación y Diagnóstico en Micología Clínica. Bilbao, 2007: ISBN: 978-84-611-8776-8.

15. Dorsthorst D., et al. "Comparison of fractional inhibitory concentration index with response surface modeling for characterization of in vitro interaction of antifungals against itraconazole susceptible and resistant Aspergillus fumigatus". Antimicrobial Agents and Chemotherapy 46.3 (2002): 702-707.

16. Semis R., et al. "Evaluation of antifungal combinations of nystatin-intralipid against Aspergillus terreus using checkerboard and disk diffusion methods". Journal de Mycologie Médicale 25.1 (2015): 63-70.

17. Díaz- Jarabrán MC., et al. "Evaluación del perfil de sensibilidad in vitro de aislamientos clínicos de Trichophyton mentagrophytes y Trichophyton rubrum aislados en Chile". Revista Iberoamericana de Micología 32.2 (2015): 83-87.

18. Chavez J., et al. "Sensibilidad in vitro de hongos miceliales de aislamientos clínicos en pacientes con cáncer en el Instituto Nacional de Cancerología ESE”. Infectio 14.2 (2010): 116-126.

19. García-Martos P., et al. "Actividad in vitro de anfotericina B, itraconazol y voriconazol frente a 20 especies de Aspergillus empleando el método de microdilución Sensititre ${ }^{\circledR ”}$. Enfermedades Infecciosas y Microbiología Clínica 23.1 (2005): 15-26.

20. Snelders E., et al. "Emergence of azole resistance in Aspergillus fumigatus and spread of a single resistance mechanism". PloS Medicine 5.11 (2008): e219.

21. Rodríguez-Tudela JL., et al. "Epidemiological cutoffs and crossresistance to azole drugs in Aspergillus fumigatus". Antimicrobial Agents and Chemotherapy 52.7 (2008): 2468-2472.

22. Mortensen K., et al. "Environmental study of azole-resistant Aspergillus fumigatus and other aspergilli in Austria, Denmark and Spain". Antimicrobial Agents and Chemotherapy 54.11 (2010): 4545-4549.

23. Mellado E., et al. "Identification of two different 14-alpha sterol demethylase-related genes (cyp51A and cyp51B) in Aspergillus fumigatus and other Aspergillus species". Journal of Clinical Microbiology 39.7 (2001): 2431-2438.
24. Neelabh, "ABC and MFS transporters: a reason for antifungal drug resistance". Archives of Biotechnology and Biomedicine 2 (2018) 001-007.

25. Meneau I., et al. "Identification of Aspergillus fumigatus multigrug transporters genes and their potential involvent in antifungal resistance". Medical Mycology 54.6 (2016): 616-627.

26. Sonthalia S., et al. "Topical ciclopirox olamine $1 \%$ : Revisiting a unique antifungal". Indian Dermatology Online Journal 10.4 (2019): 481-485.

27. Liu X., et al. "Primary cutaneous aspergillosis caused by Aspergillus fumigatus in an immunocompetent patient". Medicine 96.48 (2017): e8916.

28. Li R., et al. "In vitro susceptibility testing of amorolfine in pathogenic fungi isolated from dermatomycosis patients in China". Mycoses 47 (2004): 402-406.

29. Gupta AK., et al. "In vitro susceptibility testing of ciclopirox, terbinafine, ketoconazole and itraconazole against dermatophytes and nondermatophytes, and In vitro evaluation of combination antifungal activity". British Journal of Dermatology 149.2 (2003): 296-305

30. Chaturvedi V., et al. "Multilaboratory testing of two-drug combinations of antifungals against Candida albicans, Candida glabrata and Candida parapsilosis". Antimicrobial Agents and Chemotherapy 55.4 (2011): 1543-1548.

\section{Assets from publication with us}

- Prompt Acknowledgement after receiving the article

- Thorough Double blinded peer review

- Rapid Publication

- Issue of Publication Certificate

- High visibility of your Published work

Website: https://www.actascientific.com/

Submit Article: https://www.actascientific.com/submission.php Email us: editor@actascientific.com

Contact us: +919182824667 